\title{
Assessment of Organic Pesticides in Ground and Surface Water in Bhopal India
}

\author{
Daisy Bhat $*^{1}$ and P.Padmaja ${ }^{2}$ \\ ${ }^{1}$ R.D Foundation Group Of Institutions, NH-58, Kadrabad, Modinagar Ghaziabad(U.P) India . \\ ${ }^{2}$ Rajiv Gandhi ProdyogikiVishwavidyalaya(State Technical University)Bhopal(M.P) India
}

\begin{abstract}
Analytical assessment of surface and ground water samples for presence of organic pesticides is being reported in this paper. Analytical measurement was carried out for 15 samples each of surface and ground water collected from selected points near agricultural fields from river Betwa in Bhopal area. The sample size was stretched across 20sq.k.m.Pesticides were analysed by GLC and identified by comparing with standard reference compounds. Traces of Various pesticides including HCH $(\alpha \beta Y$ isomer),Aldrin, Endosulphan were found in all samples. Pesticide content was more in surface than ground water suggesting primary entry of pesticides into river water due to run off from nearby fields. $\beta H C H$ content was more than other isomers.
\end{abstract}

Key Words: Pesticides, Assessment, surface water, ground water, Bhopal.

\section{Introduction}

Pesticides are being used all over the world for crop control Most of the pesticides are inherently toxic, not only to the pests, against which they are used, but also to other organisms. Damage to non target organisms, perturbation of structure and function of environment and toxiccontamination of environment are few consequences of pesticide use[1-3]. Long term and rampant use of pesticides results in persistence, bioaccumulation and long range transport [4] of these hazardous chemicals. Contamination of aquatic environment due to excessive use and runoff from agricultural fields effects marine life and reduces fish production . The toxicants effect entire ecological balance and result in severe health hazards to human beings. These changes occur, so slowly, that the problem becomes visible only after it has taken a serious turn, making it very difficult to reverse the trend. There is utter need for continuous monitoring of pesticide pollution, so that some corrective measures can be taken before it is late. Recently there has been a growing interest in environmental monitoring [5-6] and regulatory activities[7-8] world over, resulting in signing of protocols and agreements globally but the situation can only be controlled by working at ground level and continuous monitoring .The objective of present study is to determine the concentration levels of organic pesticides in water,to understand the cause and effect,there by suggest suitable corrective measures.

\section{MaterialsAnd Methods}

Surface water samples were drawn from 15 points over a stretch of 20kmfrom river Betwa Near Bhopal City. Samples of ground water were collected from wells at 15 different locations in the agricultural fields, total area covered is around 20sq. km.

2.1Extraction :-A water sample of 500ml was taken in a one litre separatory funnel and $10 \mathrm{~g} \mathrm{NaCl}$ was added to it. The funnel was shaken to dissolve $\mathrm{NaC} 1$ and then $50 \mathrm{ml}$ of $15 \%$ dichloromethane in $\mathrm{n}$-Hexane was added and the pesticide extracted. The lower aqueous layer was drawn into a fresh one litre separatory funnel and reextracted twice with fresh portions of $50 \mathrm{ml}$ of $15 \%$ dichloromethane inn-Hexane.The three extracts were combined and dried by passing through an absorbent column containing a $5 \mathrm{~cm}$ layer of anhydrous $\mathrm{Na}_{2} \mathrm{SO}_{4}$ over a small pad of glass wool at the bottom. The extracts were concentrated to remove the traces of dichloromethane and finally taken in n-Hexane for GLC analysis.Analysis of pesticides was carried out by using a Nucon- Amil $5700 \mathrm{Gas}$ chromatograph, with high bore column. The temperature was maintained at $220^{\circ} \mathrm{C}$ with nitrogen as career gas and FID detector connected to a computerised recorder system. The compounds were indentified by comparing their chromatographs with those of standard compounds.

\section{Results And Discussion}

Analysis of ground and surface water samples showed presence of traces of pesticides like $\mathrm{HCH}$, including those already banned like Heptachlor, Aldrin, Endosulphansulphate inall samples under investigation. Concentration and Retention timeof pesticides found is given in TABLE 1 and 2 respectively.The concentration of $\beta, \mathrm{HCH}$ was found more than other isomers, which may be attributed to stability of this isomer especially to microbial degradation [8].In all sample the concentration of pesticide is more in surface water than ground water 
. These findings indicate that agricultural activities within the vicinity of the river has effected quality of surface water due to run off from these fields. Industrial and domestic use of pesticides also contributes to entry of these hazardous chemicals into water bodies. Absence of DDT and DDE suggests growing awareness among farmers about its ill effects, as it is already under restricted use in our country . Presence of lesser amounts of Aldrin, Endosulphansulphate and Heptachlor as compared to HCH may due to banning of these pesticides since 1996.

Table -1 Concentration of Various Pesticides in Ground and surface water.

\begin{tabular}{|l|c|c|c|}
\hline S.No & Compound & Conc. In Ground water $\boldsymbol{\mu g} / \mathbf{l}$ & Conc. In surface water $\boldsymbol{\mu}$ g/l \\
\hline 1. & $\boldsymbol{\alpha}-\mathrm{HCH}$ & 0.128 & 0.245 \\
\hline 2. & $\boldsymbol{\beta}-\mathrm{HCH}$ & 0.215 & 0.329 \\
\hline 3. & Y-HCH & 0.108 & 0.207 \\
\hline 4. & Aldrin & 0.083 & 0.147 \\
\hline 5. & Heptachlor & 0.019 & 0.118 \\
\hline 6. & Endosulphansulphate & 0.032 & 0.078 \\
\hline 7. & DDT,DDE & ND & ND \\
\hline
\end{tabular}

Table -2 Retention $\left(\mathbf{R}_{t}\right)$ Time of various Pesticides under given conditions

\begin{tabular}{|l|c|c|}
\hline \multicolumn{1}{|c|}{ S.No } & Compound & Retention time \\
\hline $1 .+$ & $\boldsymbol{\alpha}-\mathrm{HCH}$ & 14.8 \\
\hline 2. & B-HCH & 18.5 \\
\hline 3. & Y-HCH & 18.9 \\
\hline 4. & Aldrin & 34.0 \\
\hline 5. & Heptachlor & 24.0 \\
\hline 6. & Endosulphansulphate & 55.0 \\
\hline
\end{tabular}

\section{Conclusion}

The assessment clearly shows that the river water is contaminated with toxic pesticides. The amounts exceed WHO and Bureau of Indian standards parameters . There is utmost need to have more awareness as well as stricter monitoring of unauthorized use of synthetic organic pesticides for agriculture activities.Use of alternative pesticides needs to be promoted to avoid further damage and pollution.

\section{Acknowledgements}

Daisy Bhat and P.Padmaja are highly thankful to Chairman RDFGIT and Director RGPV for their support to carry out the investigation.

\section{References}

[1]. R.R. Babus, T.Imagawa, H.Tao and R.Ramesh, Distribution of PCBs, HCHS DDTs and Theirecotoxicological implications in Bay of Bangal, India, Environmental international31, 2005,503-512.

[2]. Om Prakesh, S. Mrutyunjay, R.Vishakha, C. Dogra, R.Pal and Ruplal, Residues of HCH isomers in soil and water samples from Delhi and adjoining areas, 87C1), 2004,73-77.

[3]. O.Wurl and J.P ObbardOrganichlorine pesticides, Polychlorinated and PolybrominatedDiphenyl Ethers in Singapore's

[4]. Marine Sediments, Chemosphere 58 (11) 2005, 925-933.

[5]. W.T. Now, Organochlorine Pesticides inwater, sediment, crops and human fluids in a farming community in Ghana, Archives of environmental Contamination and Toxicology, 40 C4) 2001, 557-563.

[6]. N.Lubna, N.Sharma, R.P Tyagi, and D.SJadon, Studies on organ chlorine pesticide residue in Hindon river surface water of Ghaziabad, International journal of AppliedEnvironmental Sciences,(2) 2010,692.

[7]. P.K Sethi and A.K Bhaltacharya, Current Trends of organochlorinated Pesticides in Yamuna river around Delhi, Environmental Pollution Control 2(3), 1999, 40-43.

[8]. P.Panday, P.S Khillare and K.Kumar, Assesment of organochlorine pesticide residue in surface sediments of river Yamuna, Delhi India, Journal of Environmental Protlection,2, 2011,511-524.

[9]. C. Dograetal, Organisation of len genes and 156100 among different strains of hexachlorocycloheane -degrading Sphengomonaspaucimobiles, J.Bacterial 186, 2004, 2225-2235.

[10]. A.kJorhi, M.Dua, D. Tuteja, R. Saxena, D.M. Saxena and R.Lal, Degradation of $\alpha, \beta$ Y and hexachloro-cyclohexane by SphengomonasPaucimobiles, Biotechnol. Lelt, 20, 1998, 885-887.

[11]. S.K Saheus, K.K Patnaik, K. Sharmila, and N. Setunatlan Degradation of $\alpha, \beta$ andY HCH by soil Bacterium under aerobic conditions, Applied EnviromentalMicrobilogy, 56,1990,3620-3622. 